\title{
MDW-accountancy in een ander perspectief geplaatst
}

\author{
Reactie van Prof. J.H. Blokdijk
}

\section{Inleiding}

Het MDW-rapport Accountancy (1997), door Van Schoten besproken in het voorgaande artikel. heeft in het accountantswereldje commotie veroorzaakt. In het algemeen is er afwijzend op gereageerd, en het - minstens impliciete pleidooi van Van Schoten voor de handhaving van de status quo ligt hiermee in lijn. Zelf heb ik enkele malen publiekelijk blijk gegeven van een andere mening, het meest uitgebreid in de Accountancy Nieuwsbrief van januari 1998 (Blokdijk, 1998). Daarom ga ik gaarne in op de door Van Schoten aangedragen argumenten.

Van Schoten beschouwt genoemd rapport (hierna aangeduid als MDW-rapport) vanuit ontwikkelingen die zich in verschillende segmenten van het maatschappelijk leven afspelen: het beroep en het Rijk. Ik kies een andere invalshoek: de aan het rapport ten grondslag liggende 'moticven', als door Van Schoten onderkend. die de bevordering zijn van:

de marktwerking, en

- de onafhankelijkheid, de kwaliteit en de objectiviteit van het beroep.

Deze motieven zal ik nu belichten vanuit een enigszins ander perspectief dan dat van Van Schoten.

\section{De marktwerking}

In dit kader wordt het domein van de accountants ten tonele gevoerd. Het woord 'domein" suggereert exclusiviteil, althans in de zin warin het in het MDW-rapport wordt gebruikt (zie bijvoorbeeld pagina 25). Nu wordt daarin inderdaad gesteld dat het domein van accountants in een aantal gevallen onnodig is "opgerekt' (pagina 30), maar niet 'omdat accountants naast de wetlelijke controle ook allerlei adviestaken verrichten', zoals Van Schoten ten onrechte schrijft. De oprekking wordt in het MDWrapport toegeschreven aan het feit dat naast artikel 393, Boek 2, BW nog vele andere over- heidsregelingen accountantsverklaringen eisen. In het MDW-rapport wordt de vraag gesteld of dat altijd nodig is, en zo ja, of dergelijke verklaringen ook door anderen dan accountants gegeven kunnen worden.

$\mathrm{lk}$ acht het niet uitgesloten dat de in menige overheidsregeling geëiste accountantsverklaring onnodig is; om dat vast te stellen is een gedetailleerde inventarisatie vereist, die dan ook wordt aanbevolen (pagina 30). Maar als een verklaring van een onafhankelijke deskundige zin heeft, dan is het van maatschappelijk belang dat de kwaliteit daarvan ook op enigerlei wijze door de overheid wordt bewaakt. Dit betekent dat deze activiteit tor een publiekrechtelijk te beschermen domein moet worden gerekend. In vele gevallen lijkt het zinvol dit domein aan accountants toe te wijzen.

In dat kader wordt in het MDW-rapport gesteld dat de overheid uitshitend het domein van de wettelijke controle dient te beschermen. Tot dat domein wordt, naast de reeds genoemde controles, ook de - wettelijke - controle van overheidsrekeningen gerekend (zie pagina 6). zodal ook overheidsaccountants in dat te beschermen domein passen. Dit alles lijkt mij logisch. In het MDW-rapport wordt voorgesteld daartoe een Zelfstandig BestuursOrgaan ( $\mathrm{ZBO}$ ) te vormen. Ook dat lijkt mij een goede gedachte. De bemoeienis van dit ZBO behoeft zich niet verder uit te strekken dan tol degenen die wettelijke controles uitvoeren; die zouden dan in een register moeten zijn ingeschreven. Naar mijn mening zou de toegang tot dat register beperkt moeten zijn tot die RA's en AA's die wettelijke controles ook echt kunnen uitvoeren en dat ook daadwerkelijk doen; andere titeldragers zouden daarbuiten moeten blijven, om de publieke kwaliteitswaarborg niet te doen verwateren.

In het MDW-rapport wordt voorgesteld het NIVRA en de NOvAA voort te laten bestaan als privaatrechtelijke organisaties, die privaatrechtelijke keurmerken kunnen ontwikkelen (pagina”s II en 15). Ook dit lijkt mij volstrekt logisch, en helder voor het publiek en de markt. 
De marktwerking heeft nog een ander aspect: de door Van Schoten genoemde, door accountants verrichte advieswerkzaamheden. In het MDW-rapport wordt terecht gesignaleerd dat accountants op de adviesmarki een voorsprong hebben. juist wegens de uit hun domein voortvloeiende duurzame relatie met hun cliënten (pagina 25). Daardoor ontstaat op de adriesmark1 geen 'level playing field': adviseurs die niet met accountants in één huis zitten, spelen tegen een helling op. Bovendien is het niet onwaarschijnlijk dat adviseurs die de wettelijk beschermde, doch voor vele adviesdiensten irrelevante titel van $\mathrm{RA}$ of AA dragen, in de markt een moeilijk te meten, maar ook moeilijk te rechtvaardigen voorsprong hebben op andere adviseurs die de titel moeten ontberen. Dit is een extra argument on een afzonderlijke titel te reserveren voor diegenen die in eerder bedoeld register moeten zijn ingeschreven ondat zij wettelijke controles uitvoeren.

Die titel zou naar mijn mening, met name wegens de huidige internationale bekendheid. 'registeraccountant' moeten zijn. Daarvoor is nog een ander argument aan te voeren: de aanduiding "register-" suggereert een van overheidswege gewaarborgde (minimum)kwaliteit. Bij registeraccountants'-nieuwe stijl zou dit passend zijn. doch deze constatering heeft consequenties voor andere beroepen die de aanduiding 'register-' hanteren in een geheel privaatrechtelijke context.

\section{Onafhankelijkheid, kwaliteit en objectiviteit}

Ten aanzien van dit thema concentreert Van Schoten zich op twee voorstellen in het MDWrapport:

de controle van verantwoordingen aan de overheid door een door de overheid aan te wijzen accountant, en

de scheiding van controle en advies.

\subsection{Door de overheid an te wijzen accountant}

Ten aanzien van de controle van verantwoordingen aan de overheid uit hoofde van specifieke overheidsregelingen wordt in het MDW-rapport gesteld dat de overheid als rechtstreekse opdrachtgever moet optreden. Als in het register van de in te stellen ZBO uitsluitend accountants worden opgenomen die wettelijke controles echt kunnen uitvoeren en dat ook daadwerkelijk doen, moeten naar mijn mening bedoelde opdrachten uitshitend door deze accountants worden uitgevoerd. en wel om het kennelijk maatschappelijk gewenste niveau van de controle te waarborgen. Dan lijkt mij er ook geen bezwaar tegen te bestaan dat de instelling die baat heeft bij de desbetreffende overheidsregeling zelf haar 'registeraccountant'-nieuwe stijl kiest. Indien de instelling nog geen 'registeraccountant'-nieuwe stijl zou hebben, dan moet het maatschappelijk belang bij een goede controle prevaleren boven al dan niet vermeende efficiencyvoordelen. Als men de voordelen van de 'single audit' wenst te behouden, dan leidt dit tot de keuze van een accountant met de hoogste kwaliteit die voor enig onderdeel van de 'single audit' is vereist.

Ik stem in met de uit het MDW-rapport te destilleren gedachte dat de kwaliteit van de controle voorop moet staan: dat behoort het maatschappelijk belang te zijn van iedere overheidsregeling van het accountantsberoep. Het idee om de controle uit hoofde van specifieke overheidsregelingen open te stellen voor andere beroepsbeoefenaren kan ik niel ondersteunen indien niet tevens de kwaliteit van die controle publiekrechtelijk wordt gewaarborgd. Dit laatste wordt in het MDW-rapport echter niet voorgesteld.

\subsection{Scheiding van controle en adries}

Dit is het meest controversiële thema uit het MDW-rapport. Het wordt echter in vele publicalies, en ook bij Van Schoten, naar mijn smaak te veel vanuit het belang van de opdrachtgever bij advies en te weinig vanuit het maatschappelijk belang bij de controle belicht.

Het samen in één huis opereren van accountants en andere adviseurs heeft niet alleen gevolgen voor die andere adviseurs, maar ook voor de (controlerende) accountants: doordat aan de controlecliënten ook steeds meer andere adviesdiensten worden geleverd, wordt het financiële belang bij het behoud van een controleopdracht steeds groter. Het linancieel belang is in artikel 24. lid 2 en 3 van de Gedrags- en Beroepsregels Registeraccountants (NIVRA, 1997) expliciet genoemd als een mogelijke bedreiging van de onathankelijkheid. Weliswaar meent Van Schoten te constateren dat er 'geen duidelijke signalen in de maatschappij' zijn 'dat de onafhankelijkheid 
of de onpartijdigheid van de accountant in het geding zijn', maar dat lijkt op een zekere mate van blindheid van haar kant te duiden. In de herbewerkte uitgave van het boek $D e G B R$ rerklaard signaleerden Frielink en Schilder reeds in 1993 dat er met name in het Verenigd Koninkrijk en de Verenigde Staten regelmatig kritische uitlatingen in dit opzicht worden gedaan (pagina 13). Belangrijker en actueler is. dat de International Organisation of Securities Commissions (IOSCO), de mondiale organisatie van toezichthouders op het effectenverkeer, in een persbericht in het najaar van 1997 laat weten zorg te hebben over de toenemende afhankelijkheid van accountants van de opbrengsten van adviesdiensten: natuurlijk gaat het daarbij - zoals Van Schoten terecht stelt - om de onpartijdigheid van het oordeel. De IOSCO, die ten doel heefi beleggers, en dus gebruikers van accountantsverklaringen, te beschermen, kan toch stellig als een belangrijke deelnemer aan het maatschappelijk verkeer worden gezien.

Er zijn dus twee goede redenen om 'registeraccountants'-nieuwe stijl en leveranciers van andere adviesdiensten te scheiden. In het MDWrapport wordt een zeer strikte scheiding voorgesteld, maar dat idee gaat te ver: controlerende accountants moeten 'complete' accountants kunnen blijven. Als zij bij hun controle zaken ontdekken die verbetering behoeven, moeten zij die kunnen signaleren. en ook aan kunnen geven hoe die verbetering tot stand gebracht zou kunnen worden: de 'natuurlijke adviesfunctie' moet behouden blijven. In dit opzicht deel ik de mening van Van Schoten

De grenzen van de natuurlijke adviesfunctie zijn in twee opzichten mogelijk wat onduidelijk: ten aanzien van de activiteiten en ten aanzien van de (vak)gebieden.

Met betrekking tot de activiteiten bestaat in wezen een drieluik: controleren, signaleren en adviseren. Signaleren is niet adviseren, want adviseren is raadgeven. De signalen vloeien bovendien voort uit de controle, niet uit het advies. Daarom meen ik dat signaleren in elk geval tot de controlefunctie behoort.

Ten aanzien van de adviesgebieden kan in zijn algemeenheid gesteld worden dat de natuurlijke adviesfunctie ligt op die vakgebieden, die een accountant moet beheersen om een wettelijke controle te kunnen uitvoeren. Deze vakgebieden omvatten in elk geval, naast de accountantscontrole, de externe verslaggeving, de interne berichtgeving en de administratieve organisatie alsmede het belastingrecht, zij het op een wat lager niveau.

Hiertegen kan naar mijn mening geen bezwaar bestaan. De accountantscontrole betreft de weergave van de economische consequenties van gebeurtenissen. niet de gebeurtenissen zelf. Advies omtrent die weergave, of de controleerbaarheid van de weergave, heeft dan ook een geheel ander karakter dan advies omtrent beleidsaangelegenheden; voor verslaggeving en controle bestaan ook veel duidelijkere en scherpere regels dan voor beleid. Een verbod tot het geven van adviezen hierover zou de Nederlandse accountantscontrole ook in internationaal verband snel aan aanzien doen inboeten. Bij goede adviezen is de cliënt tenslotte eerder afhankelijk van de accountant dan andersom.

Om de scheiding tussen 'complete' controlerende accountants enerzijds en leveranciers van andere adviesdiensten anderzijds effectief te maken, is een verbod van enig financieel belang tussen de twee groepen nodig: geen maatschap, geen winstpooling, geen referral fees. Of een verbod tot het optreden onder een gemeenschappelijke naam of onder sterk gelijkende namen nodig is, weet ik niet: ik vermoed dat de markt dat te gelegener tijd zelf oplost.

Een organisatie van 'complete' controlerende accountants zal uiteraard over belangrijke adviesvaardigheden beschikken: bovendien zal binnen een dergelijke organisatie een zekere mate van specialisatie optreden, ondat niet alle controlerende accountants een exact gelijke voorliefde voor alle onderwerpen op de bovengenoemde vakgebieden zullen hebben. Dan zou de gehele ontwikkeling van speciale adviesdiensten die zich vanaf het begin der jaren tachtig heeft afgespeeld. van voren af aan kunnen beginnen; dat dit gevaar niet denkbeeldig is, lijkt te kunnen worden geillustreerd aan de hand van de internationale ontwikkelingen bij Arthur Andersen. Om die te voorkomen is een verbod tot het afficheren van speciale adviesdiensten nodig; een oud en vergeten thema in het Nederlandse accountantsberoep! Wel zou een specialisatie op bepaalde bedrijłstakken of typen instellingen kenbaar moeten kunnen worden gemaakt; dat maakt de markt voor de controle doorzichtiger.

De scheiding tussen controle en advies zou 
ruwweg langs de vorengeschetste lijnen kunnen verlopen. Natuurlijk zullen er bij de uitwerking lastige afbakenings- en overgangsproblemen opduiken, maar het lijkt mij de moeite waard die op te lossen. Het is beter nu in een zekere mate van rust het beroep weer helder en eenduidig te maken, dan te wachten tot een ernstige crisis van geloofwaardigheid optreedt.

Van Schoten meent een aantal ontwikkelingen te ontwaren die door de voorstellen in het MDWrapport zouden kunnen worden geschaad; zij noemt 'corporate governance', 'internal control' en 'assurance services'. Typerend is dat zij die ontwikkelingen 'binnen het beroep' situeert. terwijl ontwikkelingen 'binnen de maatschappij' doorslaggevend behoren te zijn. Van 'corporate governance' kan in elk geval gesteld worden dat het veeleer een maatschappelijke dan een beroepsontwikkeling is.

Ten aanzien van 'assurance services' zie ik geen enkel probleem: 'assurance' wordt gegeven op basis van controle. De 'complete' controlerend accountant kan dit blijven doen: niemand heeft ooit bepleit dat controlerende accountants uitsluitend wettelijke controles zouden mogen uitvoeren! In de publiciteit rond de nieuwe term 'assurance services' wordt wel eens vergeten dat Nederlandse controlerende accountants dergelijke diensten reeds lang verlenen, zij het met een ander etiket: 'retrospectieve bijzondere onderzoeken', leidend tot 'andere accountantsverklaringen', en dergelijke. De grens ligt hier bij de accountantsdeskundigheid; slechts als men ook stiekem adviezen op andere gebieden onder het etiket 'assurance services' zou schuiven, ontstaat - terecht - een probleem.

Dat lijkt het geval bij 'corporate governance'. De rol van de accountant zou ook hier het verstrekken van een zekere mate van zekerheid moeten zijn. Ook hier zie ik in beginsel geen probleem, zolang die 'assurance' niet verder komt dan de toezichthoudende organen van de desbetreffende instelling. Een publieke 'assurance' door anderen dan de verantwoordingsplichtigen acht ik maatschappelijk ongewenst; de redenen hiertoe vallen echter buiten het bestek van dit artikel. Publieke 'assurance' door accountants acht ik bovendien zinloos indien de accountants ook zouden mogen adviseren. Accountants zullen dan al snel in de positie komen dat zij 'assurance' geven over hun eigen adviezen; bovendien kan het publiek, de ontvangers van de 'assurance', niet zien of en in welke mate dat het geval is. Als accountants publieke 'assurance' over 'corporate governance' nastreven, zouden zij de scheiding tussen controle en advies moeten verwelkomen, anders wordt die 'assurance' vroeg of laat volstrekt ongeloofwaardig. Terugkeer tot de 'core business' lijkt mij dan ook uiterst zinvol.

Van Schoten noemt 'internal control' in één adem met 'corporate governance'. Dat is niet onjuist, en als ik stel dat accountants een rol in 'corporate governance' kunnen (blijven) spelen, moet ik aannemelijk maken dat 'internal control" binnen de vakgebieden valt die een controlerend accountant voor zijn controle moet beheersen. De laatste jaren wordt veelvuldig gesteld dat 'internal control' breder is dan 'interne controle', waarmee accountants zich dan vrijwel exclusief zouden hebben beziggehouden. Ik heb dat altijd wat overdreven gevonden: de schepper van het vakgebied Administratieve Organisatie, Starreveld, heeft de administratieve organisatie altijd gezien als middel van interne controle: de administratieve organisatie levert informatie die de leiding nodig heeft om de organisatie te (blijven) beheersen, en dat is 'internal control', in de brede zin. De geleverde informatie moet voor dat doel betrouwbaar zijn, en daarvoor is interne controle nodig. Er zijn dus twee lagen van interne controle, die beide tot de 'internal control' moeten worden gerekend. De vraag is thans in concreto, of accountants ook in staat zijn de effectiviteit van de administratieve organisatie als middel van interne controle te beoordelen. Ik meen deze vraag bevestigend te kunnen beantwoorden, ook al zal - zeker - enige accentverschuiving en - mogelijk - enige bijscholing nodig zijn. De door mij beoogde scheiding tussen controle en advies behoeft deze ontwikkeling in grote lijnen niet in de weg te staan.

\section{Slot}

Samengevat stelt Van Schoten dat de aanbevelingen in het MDW-rapport niet goed bij de praktijk aansluiten. De vraag is: moet een overheid zich hier klakkeloos bij aansluiten? Heeft de overheid niet een eigen functie in dit krachtenveld, en wel het algemeen maatschappelijk belang? Hoewel ik op enige punten de conclusies in het MDW-rapport niet deel, meen ik dat daarin wel degelijk blijk gegeven wordt van zorg om het 
algemeen belang, dat van veelal anonieme en sterk gespreide gebruikers. Dit kan nu eenmaal erg moeilijk behartigd worden in de relatie tussen de (economische) grootmachten: de opdrachtgevers en de accountantsorganisaties. Het MDWrapport heeft naar mijn mening dan ook volstrekt gelijk als het stelt dat de 'behartiging van de belangen van de leden' niet tot de taak van een publiekrechtelijke organisatie behoort.

Samenvattend: in elke beschouwing over de gewenste ontwikkeling van het accountantsberoep behoort het algemeen maatschappelijk belang een hoofdrol te spelen!

\section{I T E R A T U U R}

Blokdijk, J.H., (1998), Gouden kans voor sanering accountantsberoep, In: Nieuwsbrief Accountancy, januari, pp. 3-6.

Frielink, A.B. en A. Schilder, (1993), De GBR verklaard, Stenfert Kroese.

MDW-rapport Accountancy, (1997), rapport van de werkgroep Accountancy. Secretariaat: Ministerie van Justitie en Ministerie van Economische Zaken.

NIVRA, (1997), Gedrags- en Beroepsrege/s Registeraccountants, laatstelijk gewijzigd op 18 december 1997. 